\title{
Cri du Chat Syndrome
}

\author{
TADASHI KAJII, TAKEMI HOMMA, KIYOSHI OIKAWA, MASAYUKI \\ FURUYAMA, and TAKASHI KAWARAZAKI \\ From the Department of Paediatrics, Hokkaido University School of Medicine, \\ and the Paediatric Clinic, Tonan Hospital, Sapporo, Japan
}

Since the description of the first three cases of the 'cri du chat' syndrome by Lejeune, Lafourcade, Berger, Vialatte, Boeswillwald, Seringe, and Turpin (1963), 12 patients have been reported on in whom part of the short arms of a chromosome in the 4-5 group were absent (Lejeune, Lafourcade, de Grouchy, and Berger, 1964b; Punnett, Carpenter, and DiGeorge, 1964; Eöök, Atkins, and Santesson, 1963; de Grouchy, Arthuis, Salmon, Lamy, and Thieffry, 1964; Dumars, Gaskill, and Kitzmiller, 1964; Macintyre, Staples, LaPolla, and Hempel, 1964; McCracken and Gordon, 1965; Hijmans and Shearin, 1965; Dyggve and Mikkelsen, 1965). The clinical features have all been similar; with characteristic cry, severe mental retardation, microcephaly, moon face, hypertelorism, epicanthus, antimongoloid slant of palpebral fissures, low-set ears, and abnormal dermatoglyphics.

\section{Case Report}

The patient, a female, was born on July 6,1964 . The parents were normal, and were not blood relatives. One year before the child was born the mother had an operation for right ovarian cyst and an artificial abortion at 2 months of pregnancy.

Both parents were 30 years at the patient's birth. Neither pregnancy nor delivery were eventful. The gestation lasted for 40 weeks. Birth weight 3,100 g., length $50 \mathrm{~cm}$. Feeding difficulties were noted from the beginning and the baby failed to thrive. A marked tendency to respiratory infections was present. She was admitted to hospital four times between the ages of 1 month and 8 months.

She began to control her head in the supported sitting position at 4 months. Solid foods were introduced at 7 months and were readily accepted. The first tooth erupted at 7 months.

The patient was admitted to Tonan Hospital on January 22, 1965, at 8 months of age; she was small, thin, and fretful (Fig. 1), and had a cat-like cry. The head was $37.8 \mathrm{~cm}$. in circumference (normal $43.6 \mathrm{~cm}$.), weight $6,100 \mathrm{~g}$. and height was $64 \cdot 8 \mathrm{~cm}$; other features were a round face, moderate hypertelorism, microgna-

Received May 11, 1965. thia, and malformed ears with the middle portion of the helix folded out and adherent to the antihelix. Bilateral epicanthal folds were present but were indistinguishable from those of a normal Japanese baby. The palate was intact and the mouth small but normal. No abnormality was demonstrated either in the epiglottis or in the larynx by repeated laryngoscopy. The anterior and posterior fontanelles were open. No murmur was audible over the praecordium. There was a coccygeal dimple.

The baby was not hypotonic and deep tendon reflexes were normal. She could not sit alone but could raise her head. She reached for objects but did not grasp them firmly. She appeared to be functioning at about the 3-month level.

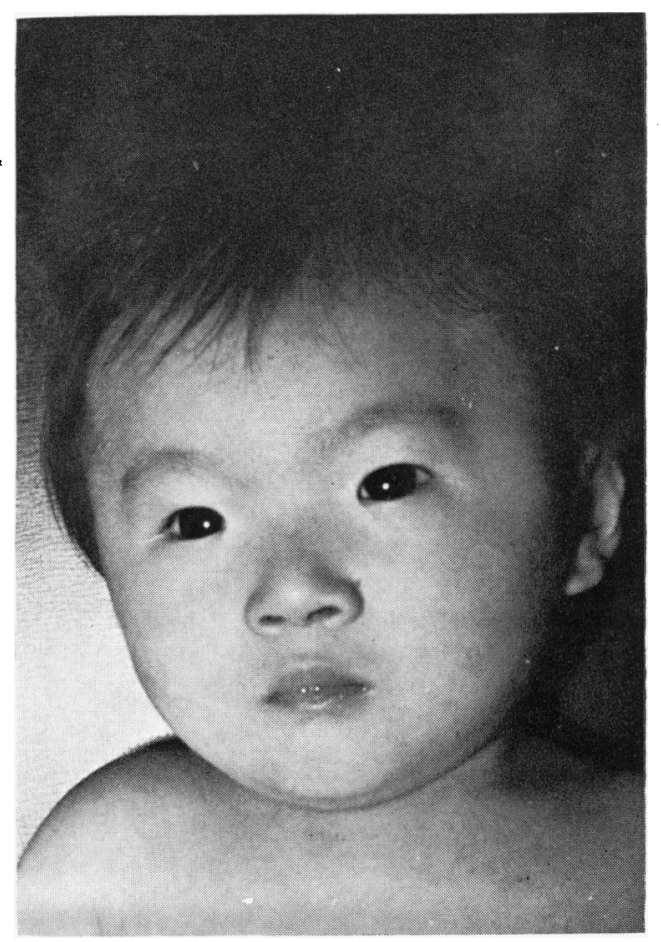

FIG. 1.-The patient at 8 months. Note round face and hypertelorism. A malformed ear and micrognathia are also present. 
The mother

The father

The patient

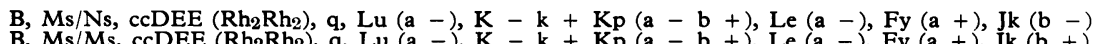

B, Ms/Ms, ccDEE $\left(R_{2} R h_{2}\right), q$, Lu $(a-), K-k+K p(a-b+), L e(a-), F y(a+), J k(b+)$

$\mathbf{B}, \mathbf{M s} / \mathbf{M s}$, ccDEE $\left(\mathbf{R h}_{2} \mathbf{R} \mathbf{h}_{2}\right), \mathbf{q}, \mathbf{L u}(\mathbf{a}-), \mathbf{K}-\mathbf{k}+\mathbf{K} \mathbf{p}(\mathbf{a}-\mathbf{b}+), \mathbf{L e}(\mathbf{a}-)$, Fy $(\mathbf{a}+), \mathbf{J k}(\mathbf{b}+)$
Laboratory investigations. Blood smears, urinalysis, serum protein, total cholesterol, calcium, inorganic phosphorus, serum electrolytes, and alkaline phosphatase activity were normal. The electrocardiogram revealed no abnormality.

Radiological examinations. The heart, skull, bone-age, and bony structure were all normal.

Cytogenetic study. Cells from the child's buccal mucosa were normal and chromatin positive. Chromosome preparations were made from the patient and both parents, using a modification of the peripheral blood leucocyte culture technique of Moorhead, Nowell, Mellman, Battips, and Hungerford (1960). The baby's blood was cultured on two separate occasions. A total of 60 cells was counted, 51 with 46 chromosomes and 9 with 45 or less. Twenty-two cells were analysed, and in all a chromosome of the 4-5 group had a major portion of the short arm missing (Fig. 2 and 3). The cells with 45 or less chromosomes showed random loss, and had probably been broken. The karyotypes of both parents were normal.
Dermatoglyphics. Significant abnormal findings included transverse palmar creases; bilateral triradii in the $t^{\prime}$ position; and an ulnar loop in the right thumb. Unlike the previously reported cases, the left thumb showed a whorl pattern.

Blood group findings. The blood group findings of the patient and her parents are tabulated (Table I) (Prof. Toshiyuki Miki, Tokyo Medical and Dental College, Department of Legal Medicine). His report, summarized in Table $I$, indicates that there is no evidence that the listed factors are controlled by genes on the deleted portion of the relevant chromosome.

\section{Discussion}

The clinical findings in the 12 reported cases and in our patient are summarized in Table II. The most striking feature of the syndrome has been a characteristic cry resembling that of a suffering kitten. This type of cry has been present in all the cases so far described except in the case reported by Dyggve and Mikkelsen (1965) in which the voice

Clinical Findings in

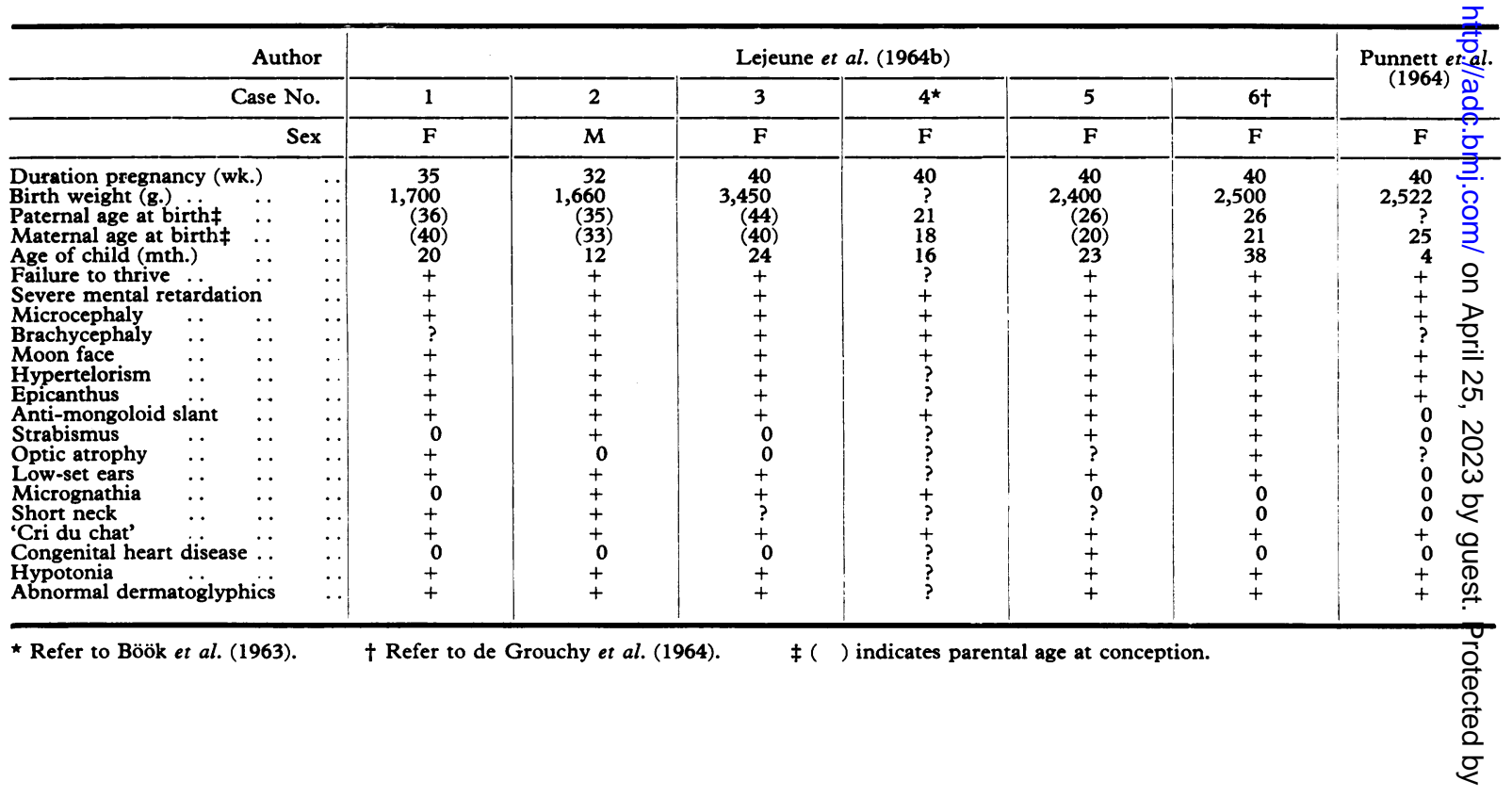




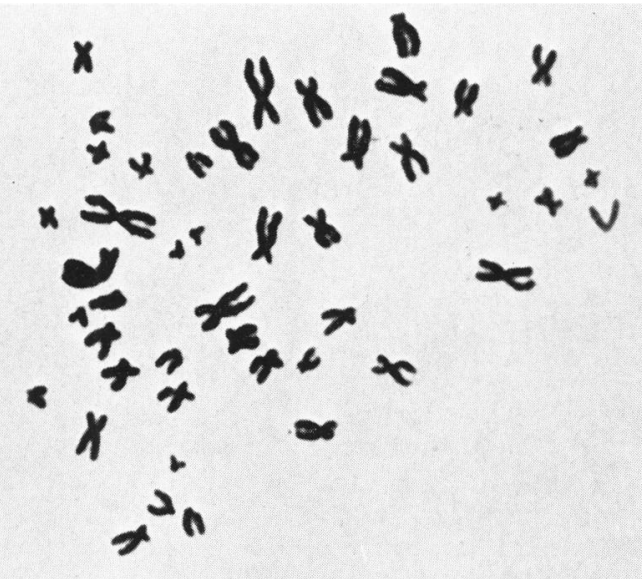

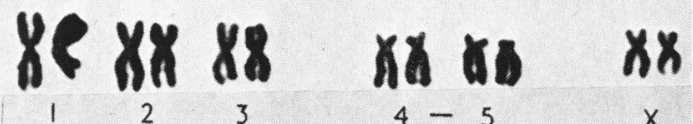

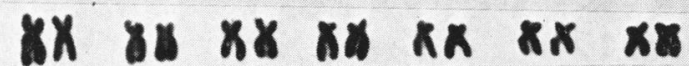

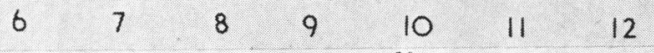

\begin{tabular}{|c|c|c|c|c|c|}
\hline$\wedge 1$ & no & A & $x x$ & An & x \\
\hline 13 & 14 & 15 & 16 & 17 & 18 \\
\hline$x x$ & $x x$ & & A A & a a & \\
\hline 10 & 20 & & 21 & 22 & \\
\hline
\end{tabular}

FIG. 2.-Karyotype of the patient showing a partly deleted short arm of one chromosome of the 4-5 group.

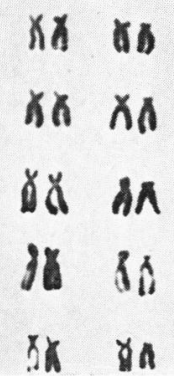

FIG. 3.-Five typical sets of chromosomes of the 4-5 group from the patient. Note the small short arms of the chromosome on the extreme right.

had a peculiar breathing character. Other features are severe growth failure, severe mental retardation, microcephaly, hypertelorism, epicanthal folds, lowset or malformed ears, and abnormal dermatoglyphics.

There is a preponderance of 11 females to 2 males, though we are aware of another case of an 8-monthold male infant (Y. Nakagome and Y. Matsui, 1965, personal communication). In 7 of the 8 cases in which the chromosome constitution of the parents was studied, it was found to be normal ( 2 cases of Lejeune et al., 1964b; Macintyre et al., 1964; McCracken and Gordon, 1965; Hijmans and Shearin, 1965; Dyggve and Mikkelsen, 1965; and the present case). But in the case reported by Lejeune, Lafourcade, Berger, and Turpin (1964a) II Cases So Far Described

\begin{tabular}{|c|c|c|c|c|c|c|}
\hline$\underset{(1964)}{\text { Dumars et al. }}$ & $\begin{array}{c}\text { Macintyre et al. } \\
(1964)\end{array}$ & $\begin{array}{l}\text { McCracken and } \\
\text { Gordon (1965) }\end{array}$ & $\begin{array}{l}\text { Hijmans and } \\
\text { Shearin (1965) }\end{array}$ & $\begin{array}{c}\text { Dyggve and } \\
\text { Mikkelsen (1965) }\end{array}$ & Present & Total \\
\hline $\mathbf{F}$ & $\mathrm{F}$ & $F$ & $\mathbf{F}$ & $\mathbf{M}$ & $\mathbf{F}$ & \\
\hline $\begin{array}{r}36 \\
2,000 \\
? \\
22 \\
7 \\
+ \\
+ \\
+ \\
? \\
+ \\
+ \\
+ \\
+ \\
0 \\
+? \\
+ \\
+ \\
? \\
+ \\
0 \\
0 \\
+\end{array}$ & $\begin{array}{r}41 \\
2,296 \\
24 \\
20 \\
7 \\
+ \\
+ \\
+ \\
+ \\
+ \\
+ \\
+ \\
+ \\
+ \\
? \\
+ \\
+ \\
+ \\
+ \\
0 \\
? \\
+\end{array}$ & $\begin{array}{c}41 \\
2,500 \\
(32) \\
(25) \\
41 \text { yr. } \\
+ \\
+ \\
+ \\
+ \\
0 \\
+ \\
+ \\
+ \\
+ \\
+ \\
+ \\
0 \\
0 \\
+ \\
+ \\
+ \\
+\end{array}$ & $\begin{array}{c}38 \\
2,160 \\
30 \\
25 \\
13 \mathrm{yr} . \\
+ \\
+ \\
+ \\
0 \\
0 \\
+ \\
+ \\
+ \\
+ \\
0 \\
+ \\
0 \\
0 \\
+ \\
0 \\
+ \\
+\end{array}$ & $\begin{array}{c}40 \\
3,200 \\
33 \\
33 \\
4 \mathrm{yr} . \\
+ \\
+ \\
+ \\
0 \\
0 \\
+ \\
+ \\
0 \\
0 \\
? \\
+ \\
+ \\
0 \\
+ \\
0 \\
0 \\
+\end{array}$ & $\begin{array}{r}40 \\
3,100 \\
30 \\
30 \\
8 \\
+ \\
+ \\
+ \\
+ \\
+ \\
+ \\
+ \\
0 \\
+ \\
0 \\
0 \\
+ \\
+ \\
+ \\
0 \\
0 \\
+\end{array}$ & $\begin{array}{r}12 / 13 \\
13 / 13 \\
13 / 13 \\
8 / 10 \\
10 / 13 \\
12 / 12 \\
12 / 12 \\
10 / 13 \\
7 / 12 \\
2 / 6 \\
10 / 12 \\
7 / 13 \\
4 / 9 \\
13 / 13 \\
2 / 12 \\
8 / 11 \\
12 / 12\end{array}$ \\
\hline
\end{tabular}



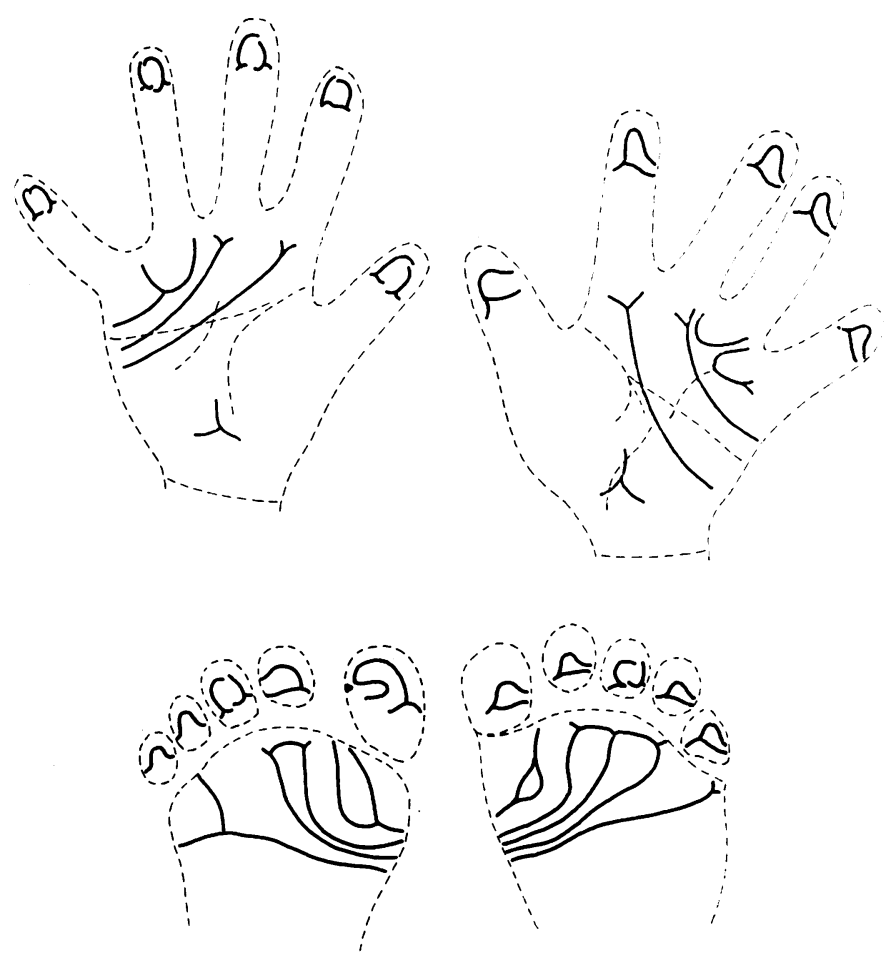

FIG. 4.-Hand and foot prints showing the main dermatoglyphic lines.

the mother showed a balanced 4-5/13-15 translocation. From this mother, the affected child received the deleted chromosome of group 4-5 but not the member of the 13-15 group to which the deleted material was attached. A similar translocation between 4-5 and a small acrocentric (21-22) has also been described in a Swedish family (Gustavson, Finley, Finley, and Jalling, 1964).

By tritiated thymidine uptake studies, German, Lejeune, Macintyre, and de Grouchy (1964) identified the chromosome with the deletion as that member of the 4-5 group in which replication is completed relatively early in the long arm and relatively late in the short arm. The other pair, which they interpret as a No. 4, replicates late throughout its total length.

\section{Summary}

Clinical and cytogenetic findings of an 8-monthold infant with 'cri du chat' syndrome are described The major abnormalities were as follows: characteristic cry, severe mental and growth retardation, microcephaly, round facies, hypertelorism, malformed ears, micrognathia, and abnormal dermatoglyphics. The chromosomal abnormality consisted of a deletion of the distal portion of the short arms of one of the 4-5 group.

Our thanks are due to Professor Toshiyuki Miki for the blood group findings, and to Miss Shizue Tsujiishi for her technical assistance in the chromosome analysis.

\section{REFERENCES}

Böök, J. A., Atkins, L., and Santesson, B. (1963). Some new data on autosomal aberrations in man. Path. et Biol., 11, 1159.

Dumars, K. W., Jr., Gaskill, C., and Kitzmiller, N. (1964). Le cri du chat (crying cat) syndrome. Amer. F. Dis. Child., 108, 533.

Dyggve, H. V., and Mikkelsen, M. (1965). Partial deletion of the short arms of a chromosome of the 4-5 group (Denver). Arch. Dis. Childh., 40, 82.

German, J., Lejeune, J., Macintyre, M. N., and de Grouchy, J. (1964). Chromosomal autoradiography in the cri $d u$ chat syndrome. Cytogenetics, 3, 347.

de Grouchy, J., Arthuis, M., Salmon, C., Lamy, M., and Thieffry, S. (1964). Le syndrome du cri du chat une nouvelle observation. Ann. Génét., 7, 13.

Gustavson, K. H., Finley, S. C., Finley, W. H., and Jalling, B. (1964). A 4-5/21-22 chromosomal translocation associated with multiple congenital anomalies. Acta paediat. (Uppsala), 53, 172

Hijmans, J. C., and Shearin, D. B. (1965). Partial deletion of short arms of chromosome No. 5. Amer. F. Dis. Child., 109, 85.

Lejeune, J., Lafourcade, J., Berger, R., and Turpin, R. (1964a). Ségrégation familiale d'une translocation 5-13 déterminant une monosomie et une trisomie partielles du bras court du chromosome 5: Maladie du 'cri du chat' et sa 'réciproque'. C.R. Acad. Sci. (Paris), 258, 5767. 
Vialatte, J., Boeswillwald, M., Seringe, P., and Turpin, R. (1963). Trois cas de délétion partielle du bras court d'un chromosome 5. ibid., 257, 3098.

- - - de Grouchy, J., and Berger, R. (1964b). Délétion partielle du bras cout du chromosome 5 . Individualisation d'un nouvel état morbide. Sem. Hôp. Paris, 40, 1069.

Macintyre, M. N., Staples, W. I., LaPolla, J., and Hempel, J. M. (1964). The 'cat cry' syndrome. Amer. f. Dis. Child., 108, 538.
McCracken, J. S., and Gordon, R. R. (1965). 'Cri du chat' syndrome. A new clinical and cytogenetic entity. Lancet, 1 , 23.

Moorhead, P. S., Nowell, P. C., Mellman, W. J., Battips, D. M., and Hungerford, D. A. (1960). Chromosome preparations of leukocytes cultured from human peripheral blood. Exp. Cell Res., 20, 613.

Punnett, H. H., Carpenter, G. G., and DiGeorge, A. M. (1964). Deletion of short arm of chromosome 5 . Lancet, 2,588 . 